WSTR-TR--91-583

DE92 017933

\title{
RADIOLOGICAL IMPACT OF PAR POND DRAWDOWN FROM LIQUID EFFLUENT PATHWAYS (U)
}

by

W. H. Carlion, et al.

Westinghouse Savannah River Company

Savarnah River Laboratory

Aiken, South Carolina 29808

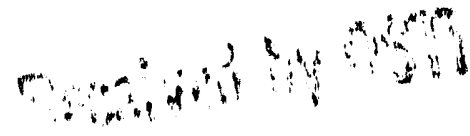

A technical report proposed for publication

This paper was prepared in connection with work done under Contract No. DE-AC09-89SR18035 with the U.S. Department of Energy. By acceptance of this paper, the publisher and/or recipient acknowledges the U.S. Government's right to retain a nonexclusive, royalty-free license in and to any copyright covering this paper, along with the right to reproduce and to authorize others to reproduce all or part of the copyrighted paper.
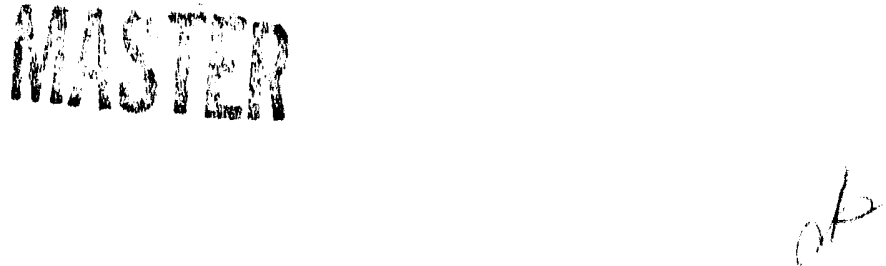


\section{DISCLAIMER}

This report was prepared as an account of work sponsored by an agency of the United States Government. Neither the United States Goverrment nor any agency thereof, orr any of their employees, makes any warranty, express or implied, or assumes any legal liability or responsibility for the accuracy, completeness, or usefulness of any information, apparatus, product, or process disclosed. or represents that its use would not infringe privately owned rights. Reference herein to any specific commercial product, process, or service by the trade name, trademark, manufacturer, or othenvise, does not necessarily corrstitute or imply its endorsement, recommendation, or favoring by the United Staces Goverrment or any agency thereof. The vieus and opinions of authors expressed herein do not necessarily state or reflent those of the United States Government or any agency thereof. 


\section{WESTINGHOUSE SAVANNAH RIVER COMPANY INTER-OFFICE MEMORANDUM}

WSRC-TR-91-583

October 25, 1991

TO: Distribution

FROM: D.M. Hamby, 773A (5-3042)

\section{RADIOLOGICAL IMPACT OF PAR POND DRAWDOWN FROM LIQUID EFFLUENT PATHWAYS}

\section{SUMMARY}

The water level of Par Pond has been lowered over the past several months to reduce the effects in the event of catastrophic dam failure while assessing the condition of the darm and determining if repairs are necessary. In lowering the level of Par Pond, 60 billion liters of water containing low levels of tritum and cesium-137 were discharged to several onsite streams. SRS surface streams flow to the Savannah River. An assessment was made to determine the total amount of tritium and Cs-137 discharged and to estimate the consequences to downstream Savannah River users.

It is estimated that a total of 160 curies of tritium were displaced from Par Pond to the Savannah River between June 28, 1991 and September 19, 1991. This release could hypothetically result in a maximum individual dose of $3.2 \times 10^{-4} \mathrm{mrem}$ and a total $(80 \mathrm{~km}$ and drinking water populations) population dose of $1.4 \times 10^{-2}$ person-rem. Likewise, a maximum individual dose of $5.0 \times 10^{-2} \mathrm{mrem}$ and a total population dose of $1.7 \times 10^{-1}$ person-rem are predicted as a result of an estimated 0.21 curies of Cs-137 being discharged from Par Pond to the Savannah River.

\section{INTRODUCTION}

Beginning in late June, water from Par Pond was pumped to onsite surface streams to lower its level and reduce the threat of catastrophic darn failure to individuals and property below the dam along Lower Three Runs Creek. Displacement of larige quantities of water ceased in mid-September when the pond surface was lowered to about 182 feet (msl). During higher than normal discharges, a total of 60 billion liters of water was withdrawn from Par Pond and discharged to onsite streams.

The radiological impact to persons using the Savannah River as a source of drinking water, aquatic foods, and recreation is assessed in this report. Data on pumping and siphoning rates, Savannah River flow rates, tritium and cesium concentrations in displaced water, 
discharge rate by outfall location, etc. were utilized to estimate tritium and Cs- 137 source terms and the pathway-specific radiation doses to a hypothetical maximum individual and the river-user populations.

The dosimetric models are normally used to estimate dose based on annual releases, uptakes, and exposures. Using the models for shorter-term assessments, on the order of months, may necessitate the use of some overly conservative assumptions. These assumptions are addressed later in this report.

\section{DISCUSSION}

\section{Savannah Rivel Flow Rates}

In order to estimate concentrations of $\mathrm{H}-3$ and Cs- 137 in the Savannah River at downstream receptor locations, an average flow rate during the period (i.e., dilution volume) was determined. During the time that the level of Par Pond was being reduced, river flow data at Highway 301 indicate that there were three periods of distinctly different flow rates.

Because of either heavy rains, discharge rates at Thurmond Dam, or both, the average Savannat kiver flow rate varied during the drawdown period. River flow data show that flow rates during July were consistently $12,000 \mathrm{cfs}$ while August flow rates averaged $19,000 \mathrm{cfs}$ and the average flow rate from September 1st through September 19th was $8,000 \mathrm{cfs}$. Given these differences and the various discharge rates, the dose assessment will be conducted assuming a fractionate release, utilizing data appropriate for each of three release periods (the months of July, August, and September).

Savannah River "effective" flow rates at the Beaufort-Jasper and Fort Wentworth water treatment facilities were determined using data from Hayes and Marter (1991). Based on that report, the "effective" flow rates are $40.3 \%$ and $26.8 \%$ greater than the Highway 301 flow rate. This increase in flow is to account for measured dilution through additional inflow of surface water between Highway 301 and the treatment facility intakes. An "effective" flow rate for the Savannah River estuary is estimated by increasing the Port Wentworth flow rate by $10 \%$.

\section{Estimation of the Total Amount of Water Discharged from Par Pond}

Daily reports from the Power Engineering Department were utilized to estimate the total volume of Par Pond water discharged to various outfalls on the SRS. For the dose assessment that follows, it is assumed that this water flows directly to the Savannah River with no loss of radioactive constituents except via radioactive decay. Calculational estimates of tritum and cesium-137 concentrations in Lower Three Runs will be given for comparison with measured concentration data. The chronology of drawdown is shown in Table 1.

Discharges from Par Pond were routed to various streams to keep impacts from erosion to a minimum. Discharge rates to these locations varied but were recorded daily by Power Engineering. According to these daily reports, of the 60 billion liters discharged, $55 \%$ went over Par Pond dam to Lower Three Runs, 27\% was directed to steel Creek (L-Lake), $11 \%$ was plimped to Pen Branch, and 7\% was discharged into Fourmile Branch.

Variability in discharge rates during the three months of drab down resulied in $16 \%$ of the total discharge being released in July, 6-4\% in Auguss, and 20\% in September. A total of 
almost 33 billion liters were discharged over the dam into Lower Three Runs; $1 \%$ in July, $62 \%$ in August, and $37 \%$ in September (Riggsbee 1991).

Table 1. Par Pond Drawdown Chronology.

Date Event

June 28

681.6G Pumphouse routes water to Steel Creek, Four-Mile Branch, and Pen Branch via the P-, L-, C-, and K-Area water lines.

July 8

4" Siphons started over dam discharging to Lower Three Runs.

July 27

Tracto: pumps added to increase discharge over Par Pond dam.

August 5

Large ( 32 \& 36 inch) siphons discharging water over the dam.

August 20

$681-60$ pumphouse shut-down so that all discharge water is now going over the dam to Lower Three Runs.

September 19

Drawdown ceases except what is required to maintain Par Pond level between $181^{\prime}$ and $182^{\prime} \mathrm{msl}$.

\section{Estimation of the 1 ritium Source Term to the Savannah River}

Before the drawdown began, tritium concentrations in Par Pond (see Figure 1) were meisured to be approximately $3.0 \mathrm{pCi} / \mathrm{mL}$ at all depths (Hayes 1991a). During drawdown, however, large amounts of rain fell resulting in a dilution of tritum in Par Pond.

Rainwater was assumed to have a tritium concentration equal the average onsite tritium concentration measured in rainwater over the past three years $(1.4 \mathrm{pCi} / \mathrm{L})$. A 3 -year average was used since an average during the drawdown period was unavailable. The average tritium concentration of water discharged from Par Pond was determined considering the volume of water initially in the pond and the volumetric increase due to rain and runoff. 
Figure 1. Tritium concentration profile in Par Pond, June 25, 1991.

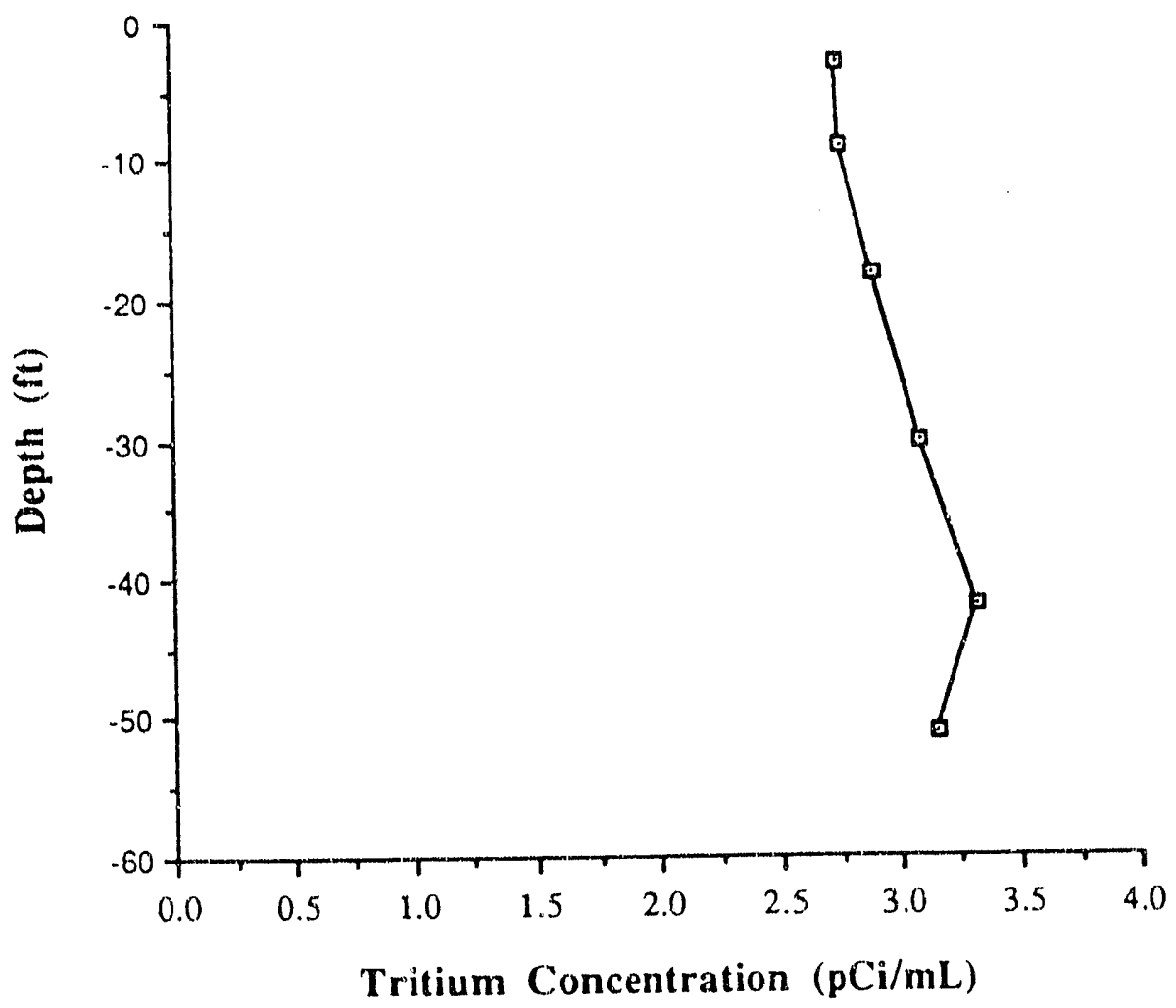

A total tritium source term of 160 curies was added to the Savannah River during the Par Pond drawdown assuming all water discharged to SR.S surface streams contained a tritium concentration of $2.7 \mathrm{pCi} \mathrm{HTO} / \mathrm{mL}$. With the discharge rates given above, the tritium source terms for the three periods of the dose assessment were calculated to be 26,102 , and 32 curies, respectively.

The total volume of Par Pond at its normal level $(200 \mathrm{ft}$. msl) has been estimated to be approximately 66 billion liters. Between June 28 th and September 19th an estimated 60 billion liters of water was removed from Par Pond by various routes. At the pond's current level (approx. $182 \mathrm{ft} \mathrm{msl}$ ) it contains about 21 billion liters. This would indicate that rain and runoff collected in Par Pond during the drawdown period totals approximately 15 billion liters.

An estimate, therefore, of the average tritium concentration in water discharged from Par Pond is approximated using the following expression:

$$
C=\frac{\left(66 \times 10^{9} \mathrm{~L}\right)\left(3.0 \frac{\mathrm{pCi}}{\mathrm{mL}}\right)+\left(15 \times 10^{9} \mathrm{~L}\right)\left(1.4 \frac{\mathrm{pCi}}{\mathrm{mL}}\right)}{\left(66 \times 10^{9} \mathrm{~L}+15 \times 10^{9} \mathrm{~L}\right)}=2.7 \frac{\mathrm{pCi}}{\mathrm{mL}}
$$




\section{Estimation of the Cesium-137 Source Term to the Savannah River}

Measurements in Par Pond prior to drawdown, shown in Figure 2 (Hayes 1991a), indicate that cesium concentrations vary with depth, ranging from about 3 to $4 \mathrm{pCi} / \mathrm{L}$ in the shallower depths ( $<30 \mathrm{feet}$ ) and 4 to $5 \mathrm{pCi} / \mathrm{h}$ at greater depths ( $>30 \mathrm{feet}$ ).

Figure 2. Cesiurn-137 concentration profile in Par Pond, June 25, 1991.

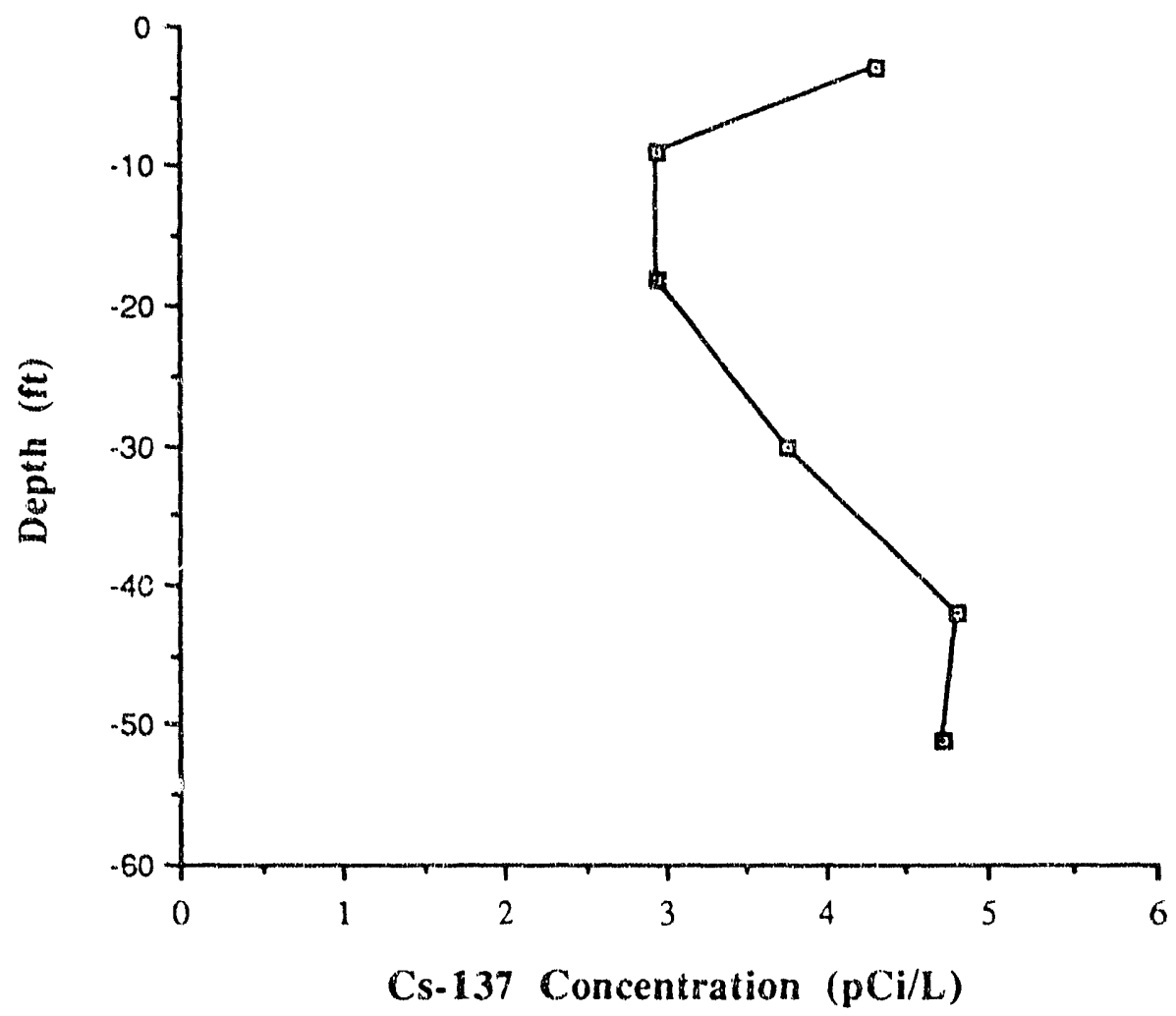

Discharge water was typically withdrawn from the shallower depths of Par Pond with an average concentration of approximately $3.5 \mathrm{pCi} / \mathrm{L}$. The inflow of runoff due to rain was assumed to have no significant affect on the cesium concentration since an equilibrium is maintained between the pond's water and cesium-bearing sediment.

Given a total discharge of $6 \times 10^{10} \mathrm{~L}$ and an average concentration of $3.5 \mathrm{pCi} / \mathrm{L}, 0.21$ curies of Cs-137 are assumed to have been displaced from Par Pond to the Savannah River during the course of drawdown. With the monthly discharge flows given earlier, the Cs-137 source terms for the three periods of the dose assessment were estimated to be 0.034 , 0.134 , and 0.042 curies, respectively. 
Calculated and Measured Tritium and Cesium-137 Concentrations in Lower Three Runs and the Savannah River

The validity of the source term estimate is checked by comparing predicted concentrations of tritium and cesium in Lower Three Runs and the Savannah River with measured values. Background concentrations measured in the Savannah River upstream of the SRS are approximately $0.2 \mathrm{pCi} \mathrm{HTO} / \mathrm{mL}$ and $0.01 \mathrm{pCi} \mathrm{Cs}-137 / \mathrm{L}$. Concentrations of $\mathrm{HTO}$ and Cs137 in Lower Three Runs and the Savannah River shown below are estimates considering only discharged activity and total flow; background and/or sediment desoprtion has not been considered.

Concentrations in Lower Three Runs are estimated assuming creek flow rates of 40, 280 . and $220 \mathrm{cfs}(18000,125000$, and $100,000 \mathrm{gal} / \mathrm{min})$ during the three release periods. Figure 3 shows flow rates in Lower Three Runs at Patterson's Mill for the period of drawdown.

Fractionating the release as specified above, 1.2, 55, and 33 curies of tritium and $0.0017,0.074$ and 0.044 curies of Cs-137 are assumed to be discharged from Par Pond to Lower Three Runs. Estimated concentrations of tritium and cesium during the months of July, August, and September are shown in Table 2.

Table 2. Estimated tritium and cesium-137 concentrations in Lower Three Runs and the Savannah River.

Assessment Period

$6 / 28-7 / 31$

$8 / 1 \cdot 8 / 31$

$9 / 1-9 / 19$

Lower Three Runs (L3Rs) Concentrations at Patterson's Mill

$\begin{array}{lccc}\text { Estimated L3Rs Flow } & 40 \mathrm{cfs} & 280 \mathrm{cfs} & 220 \mathrm{cfs} \\ \text { HTO Released } & 1.2 \mathrm{Ci} & 55 \mathrm{Ci} & 33 \mathrm{Ci} \\ \text { Calculated HTO Conc. } & 0.36 \mathrm{pCi} / \mathrm{mL} & 2.6 \mathrm{pCi} / \mathrm{mL} & 3.1 \mathrm{pCi} / \mathrm{mL} \\ & & & \\ \text { Cs-137 Released } & 0.0017 \mathrm{Ci} & 0.074 \mathrm{Ci} & 0.044 \mathrm{Ci} \\ \text { Calculated Cs-137 Conc. } & 0.51 \mathrm{pCi} / \mathrm{L} & 3.5 \mathrm{pCi} / \mathrm{L} & 4.1 \mathrm{pCi} / \mathrm{L}\end{array}$

Savannah River Concentrations at Highway 301

$\begin{array}{lccc}\text { Average River Flow } & 12,000 \mathrm{cfs} & 19,000 \mathrm{cfs} & 8,000 \mathrm{cfs} \\ \text { HTO Released } & 26 \mathrm{Ci} & 102 \mathrm{Ci} & 32 \mathrm{Ci} \\ \text { Calculated HTO Conc. } & 0.026 \mathrm{pCi} / \mathrm{mL} & 0.071 \mathrm{pCi} / \mathrm{mL} & 0.082 \mathrm{pCi} / \mathrm{mL} \\ & 0.034 \mathrm{Ci} & 0.13 \mathrm{Ci} & 0.042 \mathrm{Ci} \\ \text { Cs-137 Released } & 0.034 \mathrm{pCi} / \mathrm{L} & 0.090 \mathrm{pCi} / \mathrm{L} & 0.11 \mathrm{pCi} / \mathrm{L} \\ \text { Calculated Cs-137 Conc. } & & \end{array}$

Measured concentrations at three sampling locations on Lower Three Runs are provided in Figures 4 and 5 for tritium and cesium-137, respectively. Estimated tritium 
FIGURE 3

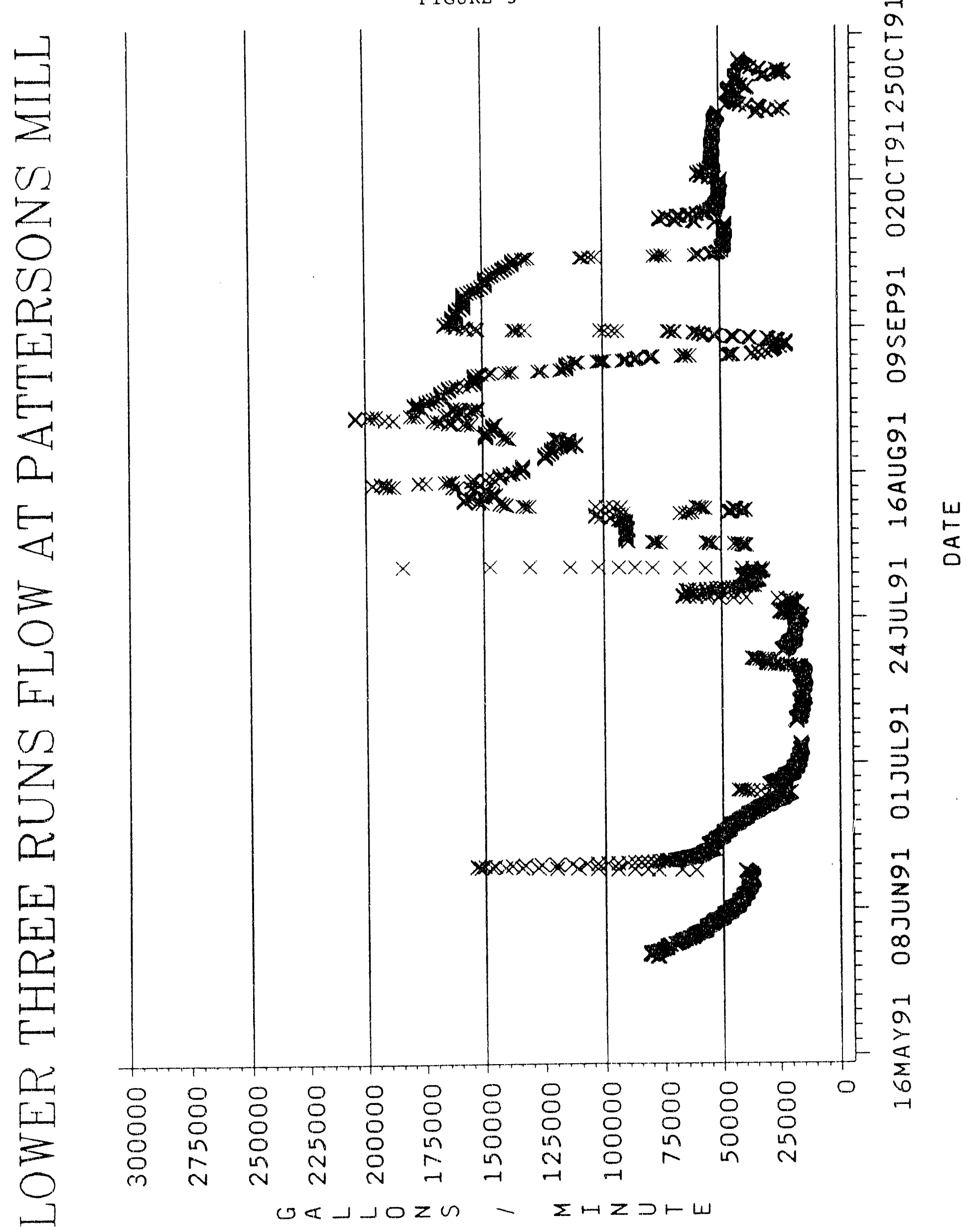


concentrations in the creek are within the range of measured values shown in Figure 4. Predicted cesium concentrations are generally a factor of 2 or 3 higher than the measured values of Figure 5. As evident in Figure 5, cesium concentrations decrease in Lower Three Runs as a function of distance from the Par Pond dam. This indicates that some fraction of the cesium is being absorbed in the sediments and that the Cs-137 source term assumption is conservative.

Measured concentrations of Cs-137 in the Savannah River (at Highway 301) averaged approximately $0.04 \mathrm{pCi} / \mathrm{L}$ during July and $0.06 \mathrm{pCi} / \mathrm{L}$ during August and September (see Figure 6). The estimated cesium concentrations shown in Table 2 are generally within a factor of 2 of these measurements. Predicted concentrations are conservatively higher than the measured values since the methodology used to estimate downstream concentrations does not consider removal (except radiological decay), resuspension, and/or additional dilution.

Figure 6. Cs-137 concentrations in the Savannah River at Highway 301.

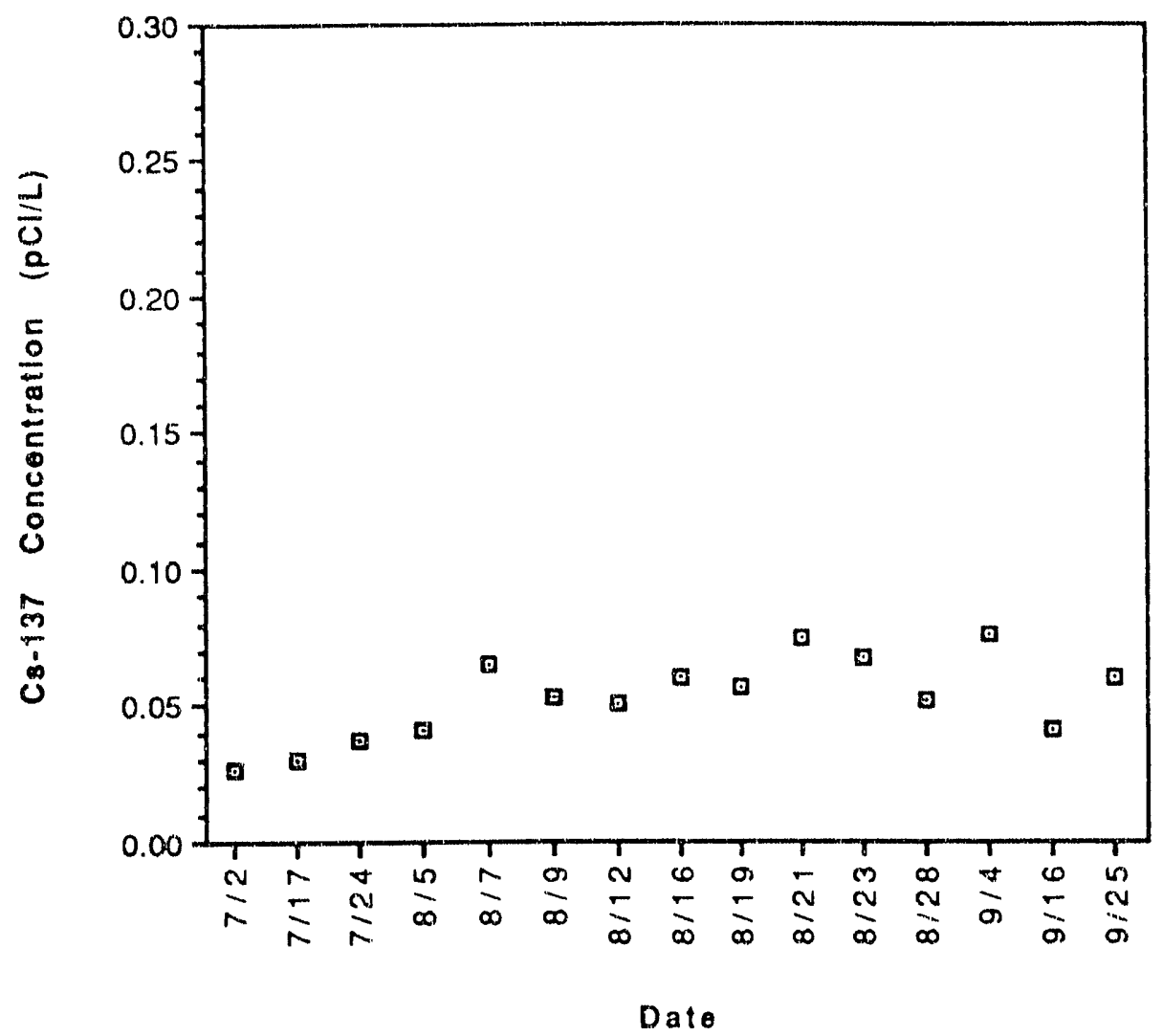

\section{Offsite Lose via Liquid Pathways}

The dosimetry models of the NRC Regulatory Guide 1.109 (LSNRC 1977) were used to estimate the radiation dose received by users of the Savannah River for drinking water, recreation, and aquatic foods consumption. The LADTAP XL spreadsheet was utilized for these calculations (Hamby 1991a). Concentrations of triturn and cesium-137 in the 


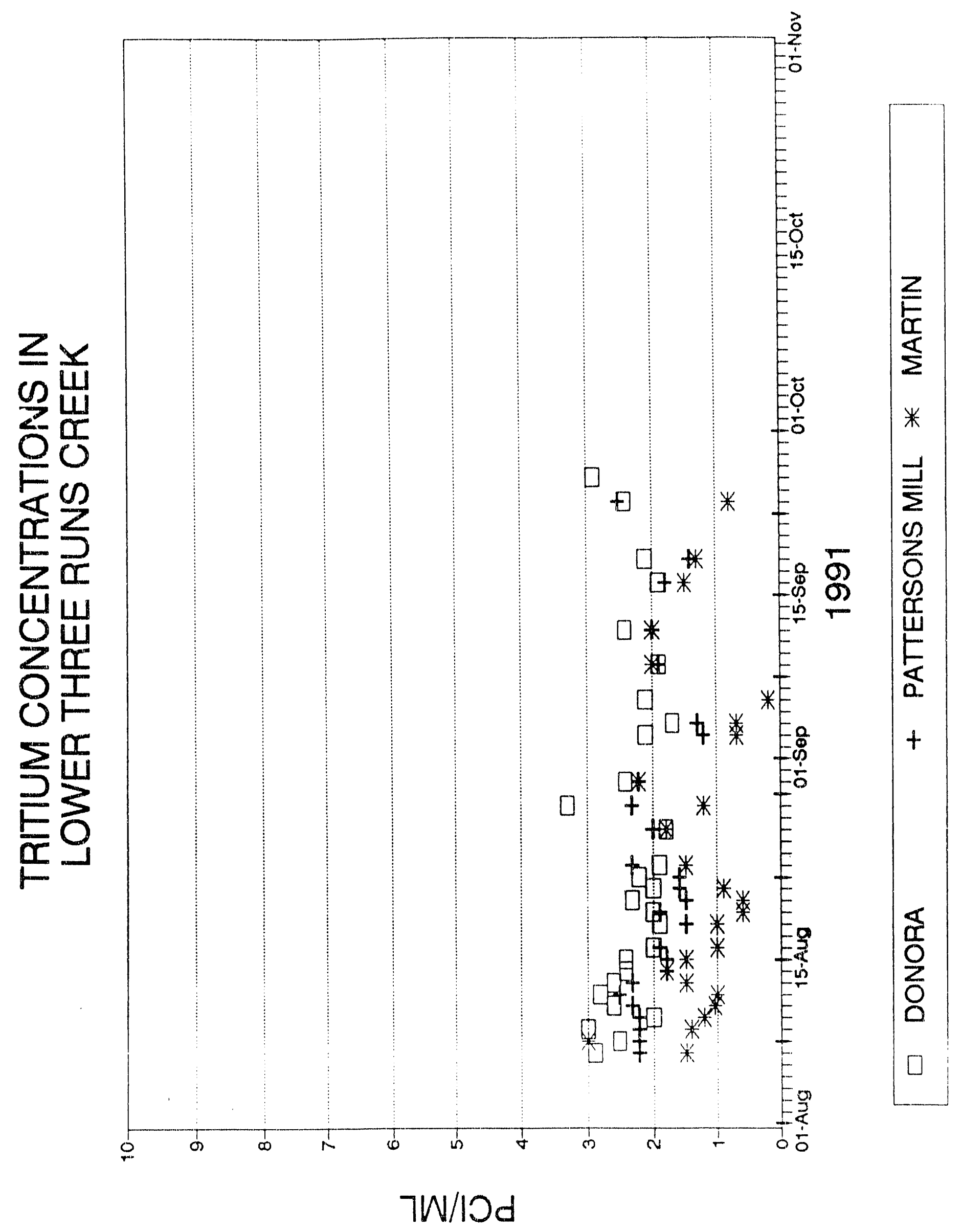




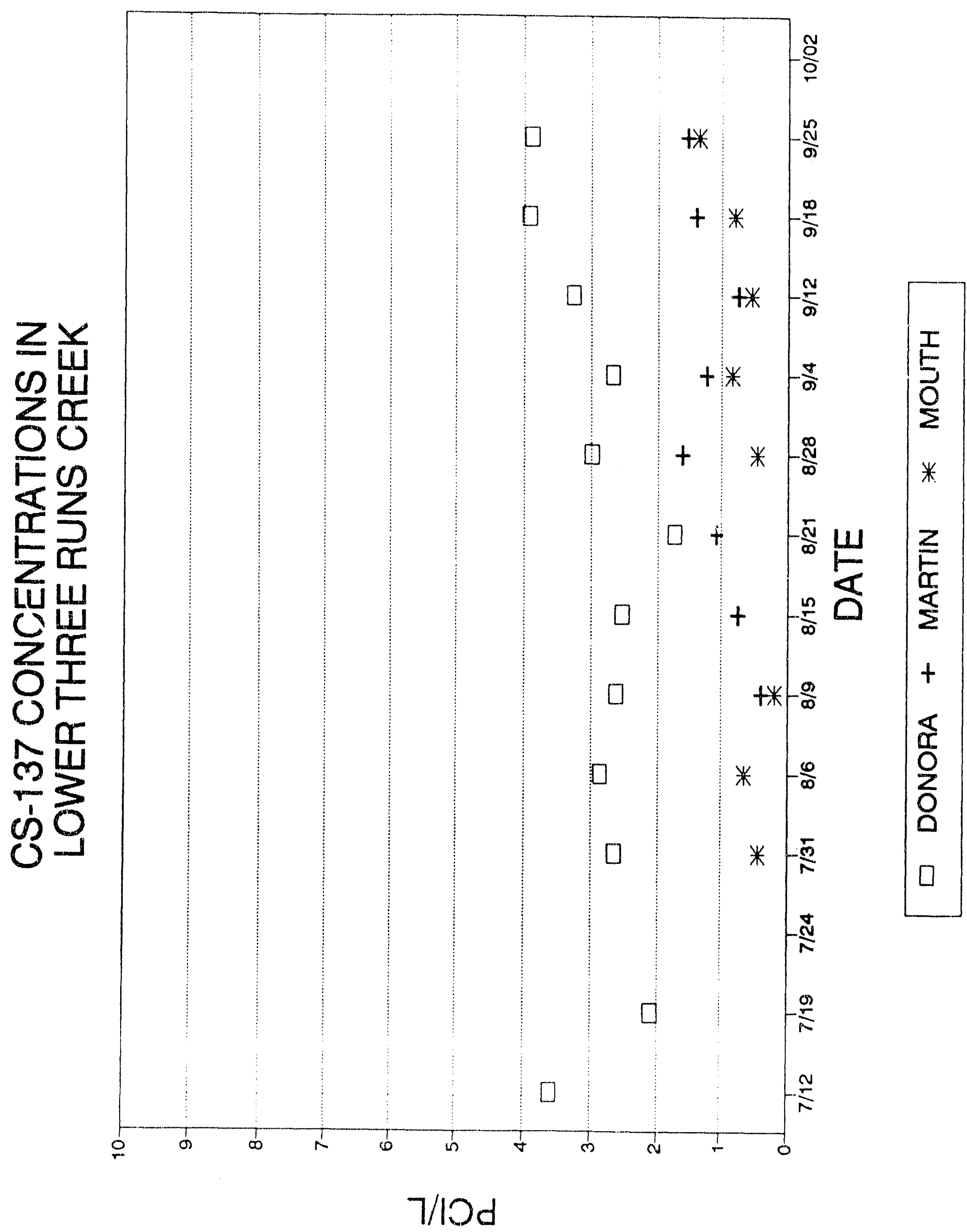




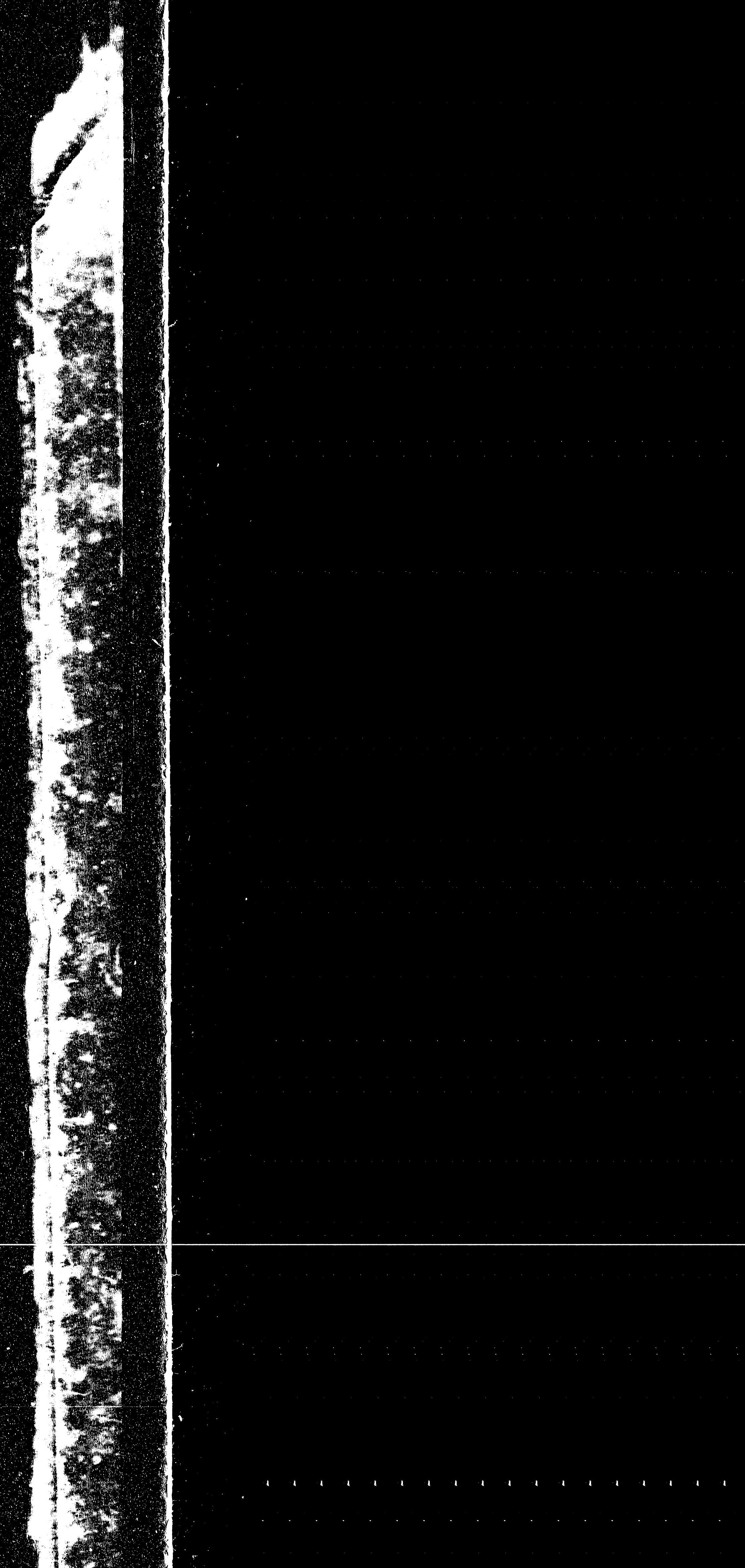


Savannah River were determined using a simple volunnetric dilution model. As stated above, three distinct river flow scenarios were used for the dose assessment to model doses received during the months of July. August, and September. A summation of these doses is the cotal dose predicted for the maximum individual and the population groups using the Savannah River.

Dose estimates using the NRC models are normally made for annual, chronic releases. Since the releases modeled here are assumed to occur over three one month intervals, several assumptions need to be made. First, it has been assumed that water, fish, and invertebrate consumption rates are constant throughout the year, i.e., an individual drinking 370 liters of water per year will drink approximateiy 31 liters per month, 7 liters per week, 1 liter per day, etc. This assumption will not result in significant over- or under-predictions for assessments where consumption is averaged over one month.

Secondly, since the drawdiswn nccurred during the later part of surimer, it is assumed that all of the individual or population recreational use of the Savannah River occurred during July, August, and September. For example, annual boating usage for the maximum individual is normally assumed to be 21 hours per year in this assessment the maximum individual boats 7 nours in each of the three months. Dose predictions via the shoreline, swimming, and boating pathways will be slightly more conservative (than for an annual dose prediction) since it assumed that all recreational activities are taking place during the release time.

Also, cesium in fish and invertebrates is assumed to reach equilibrium in a relatively short time so that the concentration of cesium in aquatic spesies can be escimated using river concentrations This assumption is most likely very conservative since the turnover rate of Cs-137 in fish is on the order of two months (Gallegos and Whicker 1971). Tri.tum is known to reach equilibrium in fish in a matter of hours (Morgan et al. 1973).

A surnmary of the Savannah River flow rates and release amounts is given in Table 3. The amounts released are assumed to enter the Savannah River over a one month period and undergo dilution based on an average flow rate estinuated for the assessment period.

Table 3. Estimated tritium and cesium-137 displaced to the Savannah River from drawdown activities at Par Pond.

\begin{tabular}{lccc} 
Assessment Period & $\begin{array}{c}\text { River Flow } \\
\text { Rate (cfs) }\end{array}$ & $\begin{array}{c}\text { Released Activity for Perior (Ci) } \\
\text { Tritium }\end{array}$ & $\begin{array}{l}\text { Cs-137 } \\
\text { June 28 - July 31 }\end{array}$ \\
\hline August 1 - August 31 & 12,000 & 26 & 0.034 \\
September 1 - September 19 & 19,000 & 102 & 0.13 \\
& 8,000 & 32 & 0.042 \\
TOTAL Activity Released & & & 0.21
\end{tabular}


Estimates of dose to the maximum individual at the sice boundary appear in Table 4. The hypothetical maximum individual at the SRS resides full-time at a location where complete mixing is assumed to have occurred. This individual drinks ordinary amounts (1 L/day) of river water and eats large amounts of Savannah River tish. He also participates in shoreline, swimming, and boating activities as specified above. A breakdown of the relative contribution of each pathway dose is given in Table 5 . The tritum dose received while swimming results from an assumed intake via skin absorption.

Table 4. Dose to the maximum individual from tritium and cesium-137 entering the Savannah River during drawdown activities at Par Pond.

Assessment Period

Effective Dose Equivalent (mrem)

Tritium

Cs-137

July

$6.0 \times 10^{-5}$

$9.5 \times 10^{-3}$

iugust

$1.5 \times 10^{-4}$

$2.3 \times 10^{-2}$

September

$1.1 \times 10^{-4}$

$1.7 \times 10^{-2}$

TOTAL Dose

$3.2 \times 10^{-4}$

$5.0 \times 10^{-2}$

Table 5. Pathway contributions to dose (maximum individual).

\begin{tabular}{lcc}
\hline & \multicolumn{2}{c}{ Percent of Max. Individual Dose } \\
Pathway & Tritium & Cs-137 \\
\hline Fish Ingestion & 4.3 & 96.7 \\
Water Ingestion & 95.4 & 0.6 \\
Shoreline & 0 & 2.7 \\
Swimming & 0.3 & $<0.1$ \\
Boating & 0 & $<0.1$ \\
\hline
\end{tabular}


Tables 6 and 7 show the predictions of maximum dose to individuals using the BeaufortJasper and Port Wentworth domestic drinking-water supplies, respectively. The maximum indivic:als at Beaufort-Jasper and Port Wentworth receive thivis dose solely from the consumption of maximum amounts $(2 \mathrm{~L} /$ day) of untreated river water.

Table 6. Dose to the downstream drinking-water maximum individual of Beaufort-Jasper.

Assessment Period

Effective Dose Equiva'ent (mrem)

Tritium

Cs- 137

July

$8.1 \times 10^{-5}$

$8.2 \times 10^{-5}$

August

$1.9 \times 10^{-4}$

$2.0 \times 10^{-4}$

Septernber

$1.5 \times 10^{-4}$

$1.5 \times 10^{-4}$

TOTAL DOse

$4.2 \times 10^{-4}$

$4.3 \times 10^{-4}$

Table 7. Dose to the downstream drinking-water maximum individual of Port Wentworth.

Assessment Period

Effective Dose Equivalent (mrem)

-

July

$8.8 \times 10^{-5}$

$9.2 \times 10^{-5}$

August

$2.1 \times 10^{-4}$

$2.2 \times 10^{-4}$

September

$1.6 \times 10^{-4}$

$1.7 \times 10^{-4}$

TOTAL Dose

$4.6 \times 10^{-4}$

$4.8 \times 10^{-4}$ 
Fist، and other aquatic species of Savannah River origin are harvested throughout the year from the Savannah River and its estuary. For the purpose of estimating a dose to the population within 80 kilometers of the SRS, it has been assumed that enough fish and invertebrates to support the 555,100 person population are harvested during each month of the assessment period. This population also participates in recreational activities in and alcng the Savannah River. Table 8 contains popilation dose estimates, in units of personrem, resulting from the predicted releases of tritium and cesium from the Par Pond drawdown. Relative contributions to the $80-\mathrm{km}$ population dose by pathway are shown in Table 9.

Table 8. Dose to the $80-\mathrm{km}$ population.

Assessment Period

Effective Dose Equivalent (person-rem)

$$
\text { Tritium Cs-137 }
$$

July

$2.2 \times 10^{-5}$

$2.9 \times 10^{-2}$

August

$5.4 \times 10^{-5}$

$7.0 \times 10^{-2}$

September

$4.1 \times 10^{-5}$

$5.4 \times 10^{-2}$

TOTAL Dose

$1.2 \times 10.4$

$1.5 \times 10^{-1}$

Table 9. Pathway contributions to dose $(80-\mathrm{km}$ population).

\begin{tabular}{|c|c|c|}
\hline \multirow[b]{2}{*}{ Pathway } & \multicolumn{2}{|c|}{ Percent of Population Dose } \\
\hline & Tritium & Cs-137 \\
\hline Sport Fish & 23 & 57 \\
\hline Commercial Fish & 2 & 4 \\
\hline Invertebrates & 60 & 1 \\
\hline Shoreline & 0 & 38 \\
\hline Swimming & 15 & $<0.1$ \\
\hline Boating & 0 & $<0.1$ \\
\hline
\end{tabular}


Population doses to the consumers of water from the Beaufort-Jasper and Port Wentworth treatment facilities are presented in Tables 10 and 11 . These doses are, again, solely from the consumption of Savannah River water. Removal of some fraction of cesium during the treatment process is not considered in the dose estimation.

Table 10. Dose to the downstream drinking-water population of BeaufortJasper.

Assessment Period

Effective Dose Equivalent (person-rem)

\begin{tabular}{lcc}
\hline July & $2.0 \times 10^{-3}$ & $2.1 \times 10^{-3}$ \\
August & $5.0 \times 10^{-3}$ & $5.1 \times 10^{-3}$ \\
September & $3.8 \times 10^{-3}$ & $3.9 \times 10^{-3}$ \\
TOTAL rose & $\mathbf{1 . 1 \times 1 0 ^ { - 2 }}$ & $\mathbf{1 . 1 \times 1 0 ^ { - 2 }}$
\end{tabular}

Table 11. Dose to the downstream drinking-water population of Port Wentworth.

Assessment Period

Effective Dose Equivalent (person-rem)

Tritium Cs-137

July

$6.8 \times 10^{-4}$

$6.8 \times 10^{-4}$

August

$1.6 \times 10^{-3}$

$1.7 \times 10^{-3}$

September

$1.2 \times 10^{-3}$

$1.3 \times 10^{-3}$

TOTAL Dose

$3.5 \times 10^{-3}$

$3.7 \times 10^{-3}$ 
The radiation dose to the total population using the Savannah River is given in Table 13.

Pathways considered include fish and invertebrate consumption; shoreline, swimming, and boating activities; and drinking water consumption. The irrigation pathway is not considered since their is no use of the Savannah River for crop irrigation known to exis: (Hamby 1991b).

Table 13. Total population dose.

tssessment Period

July

August

September
Effective Dose Equivalent (person-rem) Tritium Cs- 137

TOTAL Dose

$1.4 \times 10^{-2} \quad 1.7 \times 10^{-1}$

$1.4 \times 10^{-2} \quad 1.7 \times 10^{-1}$

$6.7 \times 10^{-3} \quad 7.7 \times 10^{-2}$

$5.0 \times 10^{-3} \quad 5.9 \times 10^{-2}$




\section{REFERENCES}

Gallegos, A.F. and Whicker, F.W., "Radiocesium Retention by Rainbow Trout as Affected by Temperature and Weight", Proceedings of the Third National Symposium on Radioecology, Oak Ridge, TN, CONF-710501-P1, pp. 361-371, May 10-12, 1971.

Hamby, D.M., "LADTAP XL: An Improved Electronic Spreadsheet Version of LADTAP II", WSRC-RP.91-975, Westinghouse Savannah River Laboratory, Aiken, SC, $1991 \mathrm{a}$.

Hamby, D.M., "L,and and Water Use Characteristics in the Vicinity of the Savannah River Site", WSRC-RP-91-17, Westingtouse Savannah River Laboratory, Aiken, SC, March 1991b.

Hayes, D.W., "Inventory and Concentration of Cs-137 and Tritium in Par Pond and Lower Three Runs Creek System", SRL-ETS-910327, Westinghouse Savannah River Laboratory, Aiken, SC, July 15, 1991 a.

Hayes, D.W. and Marter, W.L., "Historical River Flow Rates for Dose Calculations", SRL-ETS-9102.57, Westinghouse Savannah River Laburatory, Aiken, SC, June 10,1991 .

Morgan, T.J., Landolt, R.R., and Hamelink, J., "Behavior of Tritium in Fish Following Chronic Exposure", in Tritium, Moghissi, A.A. and Carter, M.W. (eds), Phoenix, Messinger Graphics, pg. 378, 1973.

Riggsbee, J.H., memo to D.M. Hamby, "Par Pond Flow to Lower Three Runs Creek", SSP-PED-910143, October 16, 1991.

US Nuclear Regulatory Commission, "Calculation of Annual Dose to Man from Routine Releases of Reactor Effluents for the Purpose of Evaluating Compliance with 10 CFR Part 50, Appendix I", Reg. Guide 1.109, Revision 1, October 1977. 


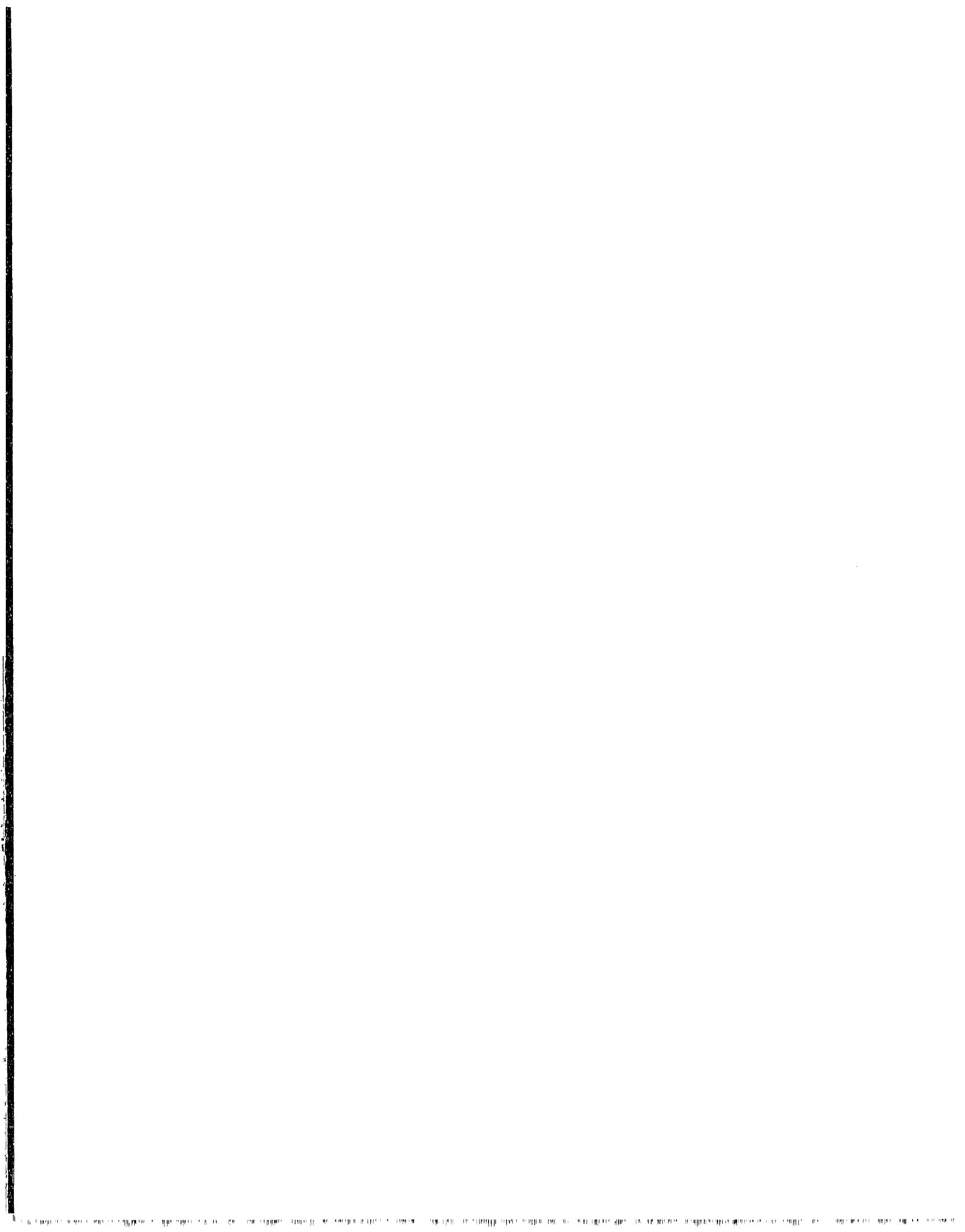

